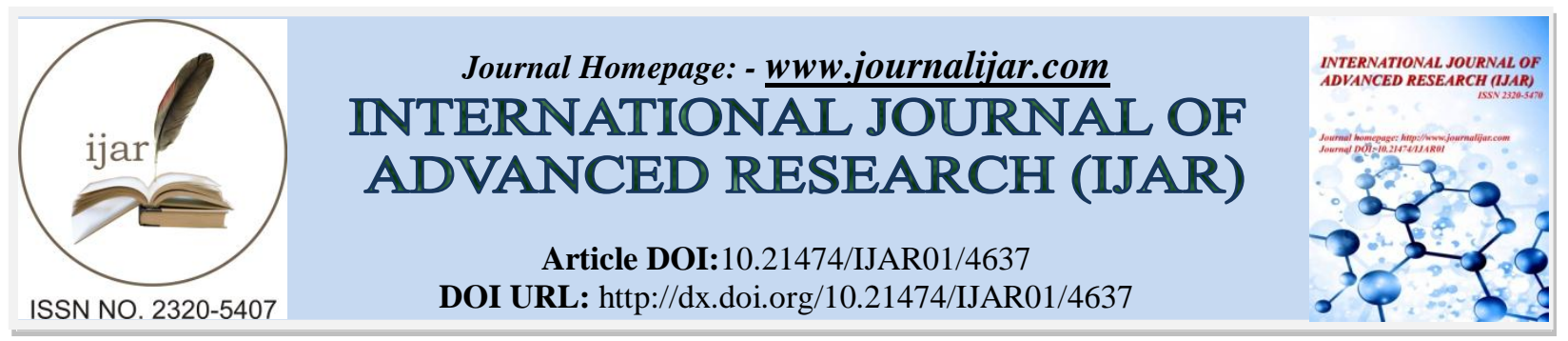

RESEARCH ARTICLE

\title{
DESIGNED FACEBOOK CLASSROOM: INNOVATION FOR IMPROVING TEACHING-LEARNING PRACTICES IN COMPUTER SCIENCE SUBJECT.
}

\author{
Eden C. Callo, Ed.D. ${ }^{1}$ and Adora C. Baguna ${ }^{2 .}$
}

1. Laguna State Polytechnic University, San Pablo City, Laguna, Philippines.

2. Department of Education, Division of San Pablo City

\section{Manuscript Info}

.........................

Manuscript History

Received: 28 April 2017

Final Accepted: 30 May 2017

Published: June 2017

Key words:-

performance, strategy, teaching, learning, effectiveness,

\section{Abstract}

This study assessed the effectiveness of the designed Facebook (FB) Classroom in improving teaching-learning practices in Computer Science (CS) subject as perceived by Grade 8 students at San Pablo City Science High School. Program Guidelines can be formulated to promote Facebook Classroom as an innovation. The study utilized a survey questionnaire and secondary data regarding the performance in Computer Science of the respondents. Frequency count, percent, mean, standard deviation, and Pearson $r$ were used to analyze the data. The hypotheses were tested at 0.05 level of significance. The salient findings of the study reveal that most of the respondents in Grade 8 are 14 years old, equally shared by male and female, whose parents were college graduates with different job types and family monthly income of Php. 22,001 and above. The respondent's performance in CS is described as Advanced (55 or $70.5 \%$ reaching 90 and above mark).The respondents agree that the designed FB Classroom when used as learning materials for delivery is effective; agree that facilitating communication is relevant to their CS performance; that collaborative learning contributes improvement in performance; and agree that curriculum content and computer skills development designed Facebook Classroom can help them achieve higher performance in Computer Science. Attitude in learning CS lessons is effective, suggesting that the use of FB Classroom motivates students bringing forth progress in their performance. There is a significant relationship between respondents' performance in CS and the perceived designed FB Classroom effectiveness particularly students' attitude, interest and motivation in learning Computer Science lessons.

Copy Right, IJAR, 2017,. All rights reserved.

\section{Introduction:-}

Teaching and learning practices differ from one school to another, from one subject-teacher to another, from one classroom to another. The task of planning, organizing and facilitating activities that will best cater the needs of students to be motivated in learning seems like a heavy weight on a teacher's shoulder. Addressing each student's needs, learning style, attitude, interest and motivation is at the center of every teacher's goals, the vision of every school and the duty of educational institutions, in general. 
Teaching-and-learning practice in a classroom today is a lot different before. Students were used to being confined to their seats for the whole day listening to long lectures, carrying heavy textbooks and felt difficulty in understanding complicated concepts. Teachers also used to depend only on chalk boards and textbooks, hardly got time to concentrate on students individually, felt difficulty in providing students with a real-life learning environment (Santosh, 2013).

Today however, some classrooms provide virtual environments in lieu of this real-life environment to sustain learning among students. This is done using technologies, in the form of devices like e-Tablets, Laptop or Desktop Computers, game-based software programs, simulations programs, and various platforms making learning possible for students. Traditional classrooms are being enhanced with technologies that improve teaching-learning practices so that students could be more engaged, responsible and accountable in their learning.

An online article in Education Week about Technology in Education (2011) states that the rapid and constant pace of change in technology is creating both opportunities and challenges for schools. Even educators at present are realizing that benefits of social networking are real. Social networking makes it possible for students to work independently and cooperatively on projects in an online environment they are familiar and comfortable with. Many schools are no longer debating whether social networking should play a role in education. Instead, the debate has shifted to what social networking tools work best and how to deploy them (Davis, 2010).

Lepi's (2014) online article "How to Use Social Media in Education" shares that the first step towards applying social media into education starts with empowering teachers by giving them freedom to use social media to engage with students and giving them the freedom to come-up with innovative ways of teaching using technology. It is up to the teachers how to apply social media to flip the conventional teaching model and make classroom and home work experience meaningful to the students.

To improve the quality of education, there is this responsibility to bring about the change in students' attitude, interest, and motivation in learning. Students seem to be motivated and interested with anything that is online. It is with this premise that this means could be used to deliver learning materials, facilitate communication or engage the students in collaborative learning since this is where they are comfortable with. By taking advantage of and maximizing the use of different educational applications, interactive activities, games and lessons at the students' fingertips at their own pace, anytime, anywhere anything now becomes possible. The challenge now lies on a teacher's hands if he or she is willing to partake in the quests to innovate, enhance, and deliver teaching-learning process just like coming out of the box.

The researchers took advantage of this opportunity by designing a Facebook Classroom hoping that it may serve as innovation tool to improve teaching-learning practices in Computer Science and provide another platform into the traditional classroom where students are exposed to different means of gathering information, utilizing effectively the data and information, and exploring different applications to learn or apply what they have learned.

The Philippines' Department of Education (DepEd) takes its share of giving opportunities to many institutions across the country with its DepEd Computerization Program. It was on July 2014 when San Pablo City Science High School received its e-Classroom consisting of 7 servers and 43 dumb terminals. As such, opportunities came great responsibility to say the least. Many teachers had already spearheaded programs and activities that took advantages of such feat.

The Facebook Classroom program designed since 2010, was encouraged by the school administrator and approved as innovation tool to improve teaching-learning practices in Information and Communications Technology (ICT) subject under the Special Programs and Projects for Curriculum Development.

\section{Conceptual Framework:-}

This study on the use of Facebook as an innovation for improving teaching-learning practices is hooked on the work of Carl Rogers who developed the theory of Facilitative Learning. With his emphasis on human potential, Carl Rogers had an enormous influence on both psychology and education, thus making him known as one of the most influential psychologists of the 20th century. He developed his approach to therapy, which he initially termed "nondirective therapy" and eventually came to be known as client-centered therapy (Cherry, 2014). 
In this theory of Facilitative Learning, Rogers claimed that the teachers are less protective of their constructs and beliefs than other teachers, more able to listen to learners, especially to their feelings, inclined to pay as much attention to their relationship with learners as to the content of the course, able to accept feedback, both positive and negative, and to use it as constructive insight into themselves and their behavior.

Furthermore, this study also utilized concepts on Socio-Constructivism and Communal Constructivism. SocioConstructivism requires a third dimension (Muttaqin, 2013), to the interaction between the learners and environment, that are, people (learners or tutors). It highlighted that learning should involve learning to learn from others and with others, and to mediate others' learning not only for their own sake but also for a collective learning. Therefore, the main elements of socio-constructivism are social, reflective, authentic, scaffolded, progressive, and experiential.

Communal Constructivism, on the other hand, is an approach to learning in which students construct their own knowledge as a result of their experiences and interactions with others and are afforded the opportunity to contribute this knowledge to a communal knowledge base for the benefit of existing and new learners. Holmes, et al. (2001), believe that communal constructivism is an expansion of social constructivism. This theory influences the design of networked learning strategies through application of information and communication technologies and is learnercentered with supportive Web-based environments. It employs principles and practice of e-learning and learners are actively engaged in the process of information generation, knowledge construction and utilization for learners' personal growth and community development.

In this context, this study aimed to assess the effectiveness of the designed Facebook Classroom in terms of learning materials delivery, facilitating communication, collaborative learning, curriculum content, and computer skills development in relation to Grade 8 students' performance in Computer Science and development in terms of their attitude, interest and motivation.

\section{Research Paradigm:}

\section{Independent Variable}

\begin{tabular}{|ll|}
\hline I. & \multicolumn{1}{c|}{ Student-Related Factors } \\
- & Attitude \\
- & Interest \\
& Motivation \\
& \\
& Facebook Classroom Assessment \\
- & Learning Materials Delivery \\
- & Facilitating Communication \\
- & Collaborative Learning \\
- & Computer Skills Development \\
\hline
\end{tabular}

Dependent Variable

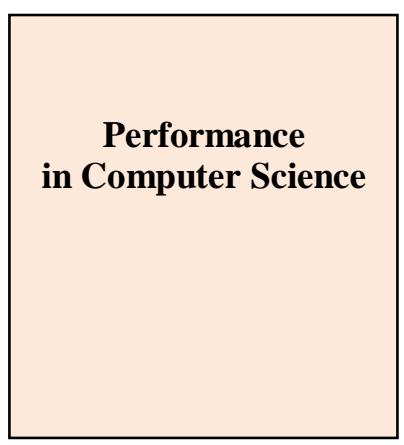

Figure 1:- The conceptual guide depicted in the research paradigm shows the relationship between variables of the study.

\section{Statement of the Problem:-}

This study assessed the effectiveness of the designed Facebook Classroom in improving teaching-learning practices in Computer Science as perceived by Grade 8 students at San Pablo City Science High School.

\section{Specifically, the study sought to answer the following questions:}

1. What is the mean performance of the respondents in Computer Science based on their Second Quarter grades?

2. What is the students' perception on the effectiveness of Facebook Classroom towards their: attitude; interest; and motivation?

3. How do the respondents perceive the level of effectiveness of the designed Facebook Classroom in terms of: 
Learning Materials Delivery; Facilitating Communication; Collaborative Learning; Curriculum Content; and Computer Skills Development?

4. Is there a significant relationship between the respondents' performance in Computer Science and the following?

4.1 perceived designed Facebook Classroom effectiveness;

4.2 Attitude;

4.3 Interest; and

4.4 Motivation?

\section{Hypotheses:-}

\section{The study posited the following hypotheses:}

There is no significant relationship between respondents' performance in Computer Science and the perceived Facebook Classroom effectiveness in terms of: Learning Materials Delivery; Facilitating Communication; Collaborative Learning; Curriculum Content; and Computer Skills Development.

There is no significant relationship between the respondents' perceived Facebook Classroom effectiveness and their: Attitude; Interest; and Motivation.

\section{Research Methodology:}

The study applied the descriptive-correlation method to observe, describe and document aspects of a situation as it naturally occurs and to serve as a starting point for hypothesis generation or theory development (Patidar, 2014).

The use of total population enabled the researcher to generalize about the subject of interest.

The study utilized a survey questionnaire assessing the perceived level of attitude, interest, motivation, and effectiveness of the designed Facebook Classroom. The instrument underwent content validation and test for reliability. It was submitted to five (5) experts in the field of education for suggestions, corrections and refinement.

After the refinement of the validated instrument, the researcher then submitted a letter asking permission from the Office of the Superintendent of Division of San Pablo City and to the Principal of San Pablo City Science High School for the conduct of the study.

The following statistical tools were employed to analyze the data: mean, standard deviation, frequency, percent and Pearson Product-Moment-Correlation Coefficient. The hypotheses were tested at 0.05 level of significance.

\section{Results and Discussions:- \\ Profile of the Respondents:-}

The profile of the respondents is defined in terms of their personal background. It is categorized into age, gender, educational attainment of parents, parents' occupation, and family monthly income.

The results indicate that majority of the Grade 8 students in San Pablo City Science High School is fourteen years of age (52 or $66.7 \%$ ); equally shared by male and female respondents; fathers and mothers are college graduates $(65.4 \%, 69.2 \%)$, respectively; 32 or $41 \%$ of fathers are employed in different types of jobs while 26 or $30.6 \%$ of the mothers are housewives. Most of the respondents have family monthly income ranging Php. 22,001 and above (27 or $34.6 \%$ )

Respondents' Performance in Computer Science.

Table 1:-Performance and Proficiency Level in Computer Science.

\begin{tabular}{|c|c|c|c|}
\hline Grade & Frequency & Percent & Description \\
\hline $90 \&$ above & 55 & 70.5 & Advanced \\
\hline $85-89$ & 19 & 24.4 & Proficient \\
\hline $80-84$ & 4 & 5.1 & Approaching Proficiency \\
\hline Total & 78 & 100 & \\
\hline
\end{tabular}

With an average grade of 90 and above, 55 or $70.5 \%$ respondents reached the "Advanced" level; 19 (24.4\%) were categorized "Proficient" level and 4 (5.1\%) were "Approaching Proficiency" level. 
The K to12 Program of the DepEd emphasized that the evidence and the quality of learning depends on the students' attainment of standards in terms of both the content and performances (Enclosure No.1 to DepEd Order No.73, s.2012). The use of Facebook Classroom as online extension of classroom activities in Computer Science subject contributes to the attainment of quality of learning as shown on the performance in every Computer Science activity and the outputs students can produce.

Students' performance on Take Home Activities and Practice Drills about Web Design and Web Programming topics that were posted on the Facebook Classroom during the Second Quarter of the school year 2014-2015 significantly demonstrated the impact of utilizing this platform. This is evident whenever take home activity sheets were turned in and checked which most of the time got everyone perfect score due to the reason that they can just easily verify their answers by searching information online. In cases of practice drills, many resources and tutorials were available online that the students can watch or download. This helped a lot during practical test since they are exposed already to how HTML (Hypertext Markup Language) tags are used and what their effects are when applied. Consequently, they get high scores during practical test. The Product (output) and Performance (practical test) are greatly affected which evidently reflected on the number of students who got the rating "Advanced", which description states: students at this level exceeds the core requirements in terms of knowledge, skills and understandings, and can transfer them automatically and flexibly through authentic performance tasks.

Science High School students are the type of students who can manage the completion of both short and extended independent or group-related tasks within the timeframes set by the teacher. They were provided with opportunities where they can create their group's plan of action in any Computer Science activities, review their work before presenting them to the class, and reflect on how they effectively manage their undertaking by assessing their work using the provided rubrics. Since everyone's participation is evaluated, using Self and Peer Assessment, they tend to ensure that their contributions are accounted for. Facebook Classroom make these possible and because the platform is interactive, students' engagement and providing feedback is beneficial.

\section{Student-Related Factors:-}

Table 2:- Attitude towards Facebook Classroom.

\begin{tabular}{|l|c|c|c|}
\hline \multicolumn{1}{|c|}{ Indicators } & Mean & SD & VI \\
\hline 1. I feel encouraged by my friends "liking" my ideas or comments. & 4.24 & 0.82 & Very Positive \\
\hline 2. I feel comfortable posting my ideas or opinions on Facebook Classroom. & 3.74 & 0.89 & Positive \\
\hline 3. I participate actively in Facebook Classroom every time there is a session. & 3.95 & 0.87 & Positive \\
\hline $\begin{array}{l}\text { 4. I prefer answering or studying learning materials through Facebook } \\
\text { classroom than in our classroom. }\end{array}$ & 3.64 & 0.88 & Positive \\
\hline $\begin{array}{l}\text { 5. I prefer discussing issues or topics on Facebook Classroom compared to } \\
\text { traditional classroom session. }\end{array}$ & 3.47 & 1.05 & Positive \\
\hline \multicolumn{1}{|c|}{ Overall } & 3.81 & 0.67 & Positive \\
\hline
\end{tabular}

Legend: VI-Verbal Interpretation; 4.21-5.0 Very Positive (VP) 3.41-4.2-Positive (P) 2.61-3.4- Non-committal (NC) 1.81-2.6-Negative (N) 1.0-1.8-Very Negative (VN)

The perceived attitude of Science high school students reveals positive (mean=3.81, SD=.67) on how the designed Facebook Classroom is an effective medium in bringing them to more interactive learning environment. Social media has the capacity to enhance student learning given the right orientation on how to use responsibly.

Students report high comfort levels and usage of social media in their personal lives, and find that the willingness to use Facebook as an educational tool varies depending on the student's chosen field of study.

Table 3:-Level of Interest towards Facebook Classroom.

\begin{tabular}{|c|c|c|c|}
\hline Indicators & Mean & SD & VI \\
\hline 1. I find it easier to complete my tasks after participating in Facebook group discussion. & 3.99 & 0.76 & $V F$ \\
\hline 2. I'm looking forward for more future integrations of classroom activities using Facebook. & 4.21 & 0.71 & $E F$ \\
\hline $\begin{array}{l}\text { 3. Brainstorming on Facebook group helps organize my thoughts before the actual } \\
\text { classroom sessions. }\end{array}$ & 4.18 & 0.70 & $V F$ \\
\hline $\begin{array}{l}\text { 4. I enjoy doing task when it is done in Facebook Classroom as extension of the classroom } \\
\text { activities. }\end{array}$ & 4.13 & 0.81 & $V F$ \\
\hline
\end{tabular}




\begin{tabular}{|c|c|c|c|}
\hline 5. Ideas or opinions posted by my peers on Facebook group help me in getting a better idea & 4.32 & 0.69 & $E F$ \\
\hline for the lessons to be tackled. & 4.16 & 0.61 & $V F$ \\
\hline
\end{tabular}

Legend: VI-Verbal Interpretation; 4.21-5.0 Extremely Favorable (EF) 3.41-4.2- Very Favorable (VF) 2.61-3.4Moderately Favorable (F) 1.81-2.6-Less Favorable (FF) 1.0-1.8 - Unfavorable (U)

The level of interest towards the development of designed Facebook Classroom generates a "very favorable" response. However, students found it "extremely favorable" when "Ideas or opinions posted by my peers on Facebook group help me in getting a better idea for the lessons to be tackled" (mean=4.32, SD=0.71). Most of the respondents are looking forward to use Facebook as a platform for understanding lessons without the pressure and critical presence of classmates in doing classroom activities

Modern communication technology developed different social networks such as Facebook, twitter, and become vital to one's life. The rapid change in the use of those media greatly change students' way of life. On-line social networking build communities of people and their everyday interaction surely brought impact on the way the students study and learn. Social networks have evolved to become virtual communities where people communicate, and share information.

Table 4:- Level of Motivation on Facebook Classroom.

\begin{tabular}{|c|c|c|c|}
\hline Indicators & Mean & SD & VI \\
\hline $\begin{array}{l}\text { 1. I tend to study hard and make sure all my answers are correct before I share them on } \\
\text { the Facebook Classroom. }\end{array}$ & 4.14 & 0.69 & $A / H M$ \\
\hline $\begin{array}{l}\text { 2. Reading the presentations first on Facebook Classroom motivates me to listen and } \\
\text { participate during actual output presentations. }\end{array}$ & 4.38 & 0.67 & $S A / E M$ \\
\hline $\begin{array}{l}\text { 3. I get motivated whenever I see my classmates participate actively in answering or } \\
\text { studying learning materials when it's done in Facebook. }\end{array}$ & 4.23 & 0.66 & $S A / E M$ \\
\hline $\begin{array}{l}\text { 4. Teacher's and students' feedback about my outputs posted on Facebook Classroom's } \\
\text { wall give me encouragement and sense of achievement. }\end{array}$ & 4.33 & 0.66 & $S A / E M$ \\
\hline $\begin{array}{l}\text { 5. It's more engaging to work on electronic materials because I can practice different } \\
\text { skills I learned in Computer Science than working on paper-based worksheets. }\end{array}$ & 4.23 & 0.77 & $S A / E M$ \\
\hline Overall & 4.32 & 0.54 & $S A / E M$ \\
\hline
\end{tabular}

Legend: VI -Verbal Interpretation; 4.21-5.0 Strongly Agree (SA)/Extremely motivated 3.41-4.2-Agree (A)/ Highly motivated 2.61-3.4-Moderately Agree (MA)/ Motivated 1.81-2.6-Disagree(D)/Less Motivated 1.0-1.8 -Strongly Disagree (SD/ Not at all Motivated)

Majority of the respondents "strongly agree" that the designed Facebook Classroom adds to their enthusiasm in bringing the lesson into an enhanced virtual learning environment, mean $=4.32, \mathrm{SD}=0.54$, extremely motivated. The indicator, "Reading the presentations first on Facebook Classroom motivates me to listen and participate during actual output presentations" generates the overall assessment of "extremely motivated".

Since students are required to post PowerPoint presentations on the Facebook Classroom Wall before delivering it to the classroom during output presentation, it allows them to read and take down notes about the topics and they can discuss and post questions about the content of the said presentations. Hence, output presentations and discussions become meaningful because students are motivated to listen and participate and the teacher can easily steer to the most important aspects of the content presentation. This is contrary to the scenario when output presentation (PowerPoint presentation for Topic Report) is only done during class time. They tend to divide their attention between note taking and listening and there is this tendency that questions asked cannot be properly addressed due to time constraints.

A study by Williams and Williams (2011) states that motivation is probably the most important factor that educators can target to improve learning. The fact is that human beings in general and students are complex creatures with complex needs and desires. Regarding students, very little if any learning can occur unless students are motivated on a consistent basis. The five key ingredients impacting student motivation are: student, teacher, content, method/process, and the environment. Facebook Classroom caters to these five key ingredients along other tools and facilities the Internet can provide so that students can easily explore and utilize while going through class-related activities online. 
Assessing the Level of Effectiveness of Facebook Classroom.

Table 5:-Perceived Level of Effectiveness of the Designed Facebook Classroom.

\begin{tabular}{|c|c|c|c|c|}
\hline Variables & Mean & SD & VI & Level of Effectiveness \\
\hline 1. Learning Materials Delivery & 3.97 & 0.58 & $A$ & Much Effective \\
\hline 2. Facilitating Communication & 4.06 & 0.61 & $A$ & Much Effective \\
\hline 3. Collaborative Learning & 4.01 & 0.54 & $A$ & Much Effective \\
\hline 4. Curriculum Content & 4.28 & 0.51 & $S A$ & Very Much Effective \\
\hline 5. Computer Skills Development & 4.39 & 0.49 & $S A$ & Very Much Effective \\
\hline Overall & 4.142 & 0.049 & SA & Very Much Effective \\
\hline
\end{tabular}

Legend: VI -Verbal Interpretation; 4.21-5.0 Strongly Agree/Very much Effective (SA) 3.41-4.2-Agree / Much Effective (A) 2.61-3.4-Effective / Moderately Agree (MA) 1.81-2.6-Disagree(D)/Less Effective 1.0-1.8 -Strongly Disagree (SD)/Not Effective

The Science High School students perceived the effectiveness of the Designed Facebook Classroom in terms of five variables. Learning Materials Delivery emphasizing the indicator "I prefer Facebook Classroom because it makes the learning materials accessible once they are downloaded in my tablet or smart phone" was strongly agreed (mean $=4.80, S D=0.86$ ) by the respondents implying it is an effective tool.

Strategies, techniques or platforms to maximize the use of Computer Science time was been the main goal. Many times, answering and checking of activity worksheets cover most of the period if not all. Utilizing Facebook Classroom, submission, completion and collaboration help a lot in accomplishing tasks like output assessment and evaluation. This design is also beneficial because it provides lots of different opportunities in learning the materials in advance once downloaded in other devices of the students. Students have the access to submit their outputs electronically through Wall comments or Wall post or via Private Message.

Facebook classroom is much effective in facilitating communication (mean $=4.06, \mathrm{SD}=0.61$ ) since Facebook is a website that allows users to interact and collaborate within a pre-defined virtual community. It is an online communication tool allowing users to construct a public or private profile to connect and interact with people who are part of their extended social network (Ellison \& Boyd, 2007).

Respondents "strongly agree" that combined information gathered in a group task, sharing ideas and exchanging resources with each other through the designed Facebook Classroom effectively bring student to more learning. Majority of the respondents "agree" that collaborative learning is a must in producing quality output, mean=4.01, $\mathrm{SD}=0.54$. Facebook enables students to articulate their misconceptions about content areas, rather it constituted an informal, innovative proxy for lecturers' prognosis and diagnostic assessment of student understanding. Facebook offered a "cozy," less threatening space for student discussion of the technical challenges they were confronted with in their courses and opportunities for soliciting their redress.

The designed Facebook Classroom is utilized in the presentation of Curriculum Content. The findings of the study suggest students "strongly agree" that provision of the curriculum content in the designed Facebook Classroom made it easier to access them and work on them as indicated in the result (mean=4.28, $\mathrm{SD}=0.51$ ).

Davis (2010) pointed out in her article at Education Week: Digital Directions, that in some schools, social networking has change the way educators teach and students learn. Social networking can mean using ready-made platforms like Facebook, but it can also be about networks that schools create specially for their students. Social networking is allowing teachers, who often feel isolated in their classrooms, to revolutionize the way they connect with others. Facebook Classroom is significant in the presentation of curriculum content where students could go back to the contents that the class had already covered whenever they miss a lecture or an activity. The students also agreed that it becomes easier to learn the content in Computer Science through Facebook Classroom because they could just browse through different references online whenever they access learning materials on it.

Respondent's perception towards Computer Skills Development is interpreted "very much effective" (mean=4.39, $\mathrm{SD}=0.49$ ). Knowledge and ability to utilize computers and related technology efficiently can be very important skill to possess. 
In the article, "Why Integrate Technology into the Curriculum? The Reasons Are Many," states that integrating technology into classroom instruction means more than teaching basic computer skills and software programs in a separate computer class. Effective technology integration must happen across the curriculum in ways that research shows deepen and enhance the learning process. It must support four key components of learning: active engagement, participation in groups, frequent interaction and feedback, and connection to real-world experts. Effective technology integration was achieved when the use of technology was routinary and transparent and when technology supported curricular goals.

Accordingly, learning through projects while equipped with technology tools allowed students to be intellectually challenged while providing them with a realistic snapshot of what the modern office looks like. Through projects, students acquired and refined their analysis and problem-solving skills as they worked individually and in teams to find, process, and synthesize information they have found online. The myriad resources of the online world also provided each classroom with more interesting, diverse, and current learning materials. The Web connected students to experts in the real world and provided numerous opportunities for expressing understanding through images, sound, and text. New technology tools for visualizing and modeling, especially in the sciences, offered students ways to experiment and observe phenomenon and to view results in graphic ways that aid in understanding (Edutopia, 2008).

Relationship between Variables:-

Table 6:-Correlation between Respondents' Performance in Computer Science and Perceived Level of Designed Facebook Classroom Effectiveness

\begin{tabular}{|c|c|}
\hline Related Factors & r-value \\
\hline Learning Materials Delivery & $.256^{*}$ \\
\hline Facilitating Communication & $.223^{*}$ \\
\hline Collaborative Learning & $.236^{*}$ \\
\hline Curriculum Content & $.233^{*}$ \\
\hline Computer Skills Development & $.334^{* *}$ \\
\hline
\end{tabular}

Note: $N=78, * * * r$-value is significant at $p<.000 ; * *$ significant at $p<.001 ; *$ significant at $p<.05$

As revealed by the test of correlation between the students' performance in Computer Science and perceived level of effectiveness of the designed Facebook classroom related variables, eg. learning materials delivery, significant relationship exists, $(\mathrm{r}=.256, \mathrm{p}=.024)$. Likewise, facilitating communication (.223), collaborative learning (.236) and curriculum content (.233) show significant relationships with the student performance in Computer Science at $\mathrm{p}$ value <.05. Lastly, computer skills development shows a high significant relationship with performance of students in the said subject $(\mathrm{r}=.334, \mathrm{p}=.003)$.

Learning Materials Delivery via designed Facebook Classroom played a significant role in the performance of Grade 8 students. This can be attributed to the fact that lessons, outputs, worksheets, assessment could easily be delivered, downloaded and worked on when posted on the said platform. The environment also allowed easy access to other information (tutorials, blogs, information sheets about Web designing, etc.) and practicing the effects of the HTML tags that they needed to learn in Web programming were just under their fingertips. Also, both teacher-made and student-made activities could easily be delivered thus, exposed them in many undertakings that made them responsible to their own learning and allows transfer of these learning in their product and performances in and out of the classroom.

The researchers viewed Facebook Classroom not only as innovation tool but also an intervention in facilitating teacher-student and student-to-student communication. Because of the diverse communication facilities that the platform offers, i.e. chat, video-chat, private message, etc. many of the classroom activities are made possible during times that face-to-face interaction cannot be facilitated. These benefited both the students and the teacher because the message, comment, post could be addressed or paid attention to not only by the teacher but by other students as well giving importance to students' inquiries, prompts and answers. This was difficult in classroom setting because teacher cannot accommodate inquiries all at the same time. Many times, students help each other by citing sites that provide answers to their questions, share their experiences, and encourage each other in doing the task whether in individual or group tasks. 
Because the platform allowed facilitation of communication, collaborative learning was also achieved. Facebook Classroom was significant in the students' performance since many of the activities in Computer Science were group-based. Allowing them to communicate in an anywhere and anytime format that made collaborative activity outside the school became possible. Hence, learning to cope up with tasks, dividing them, working on them and taking responsibility of the group members' progress established to be beneficial for both teacher and students. If other students did not have internet connection at home to participate as scheduled by their leaders, their tasks were done inside the classroom hence, they still had contributions and got points for participation. Such activities also trained them in managing time because the practice in Computer Science reporting was Action Plan, creation was the first phase. This exposes them in identifying tasks, sequencing them, distributing them among members and scheduling them. This process when imbibed can be applied across subjects which would help them in maximizing and managing their activities in and outside the school premises.

Since one of the researchers oversaw the development and design of the Curriculum Content in each grading period, utilizing Facebook Classroom proved to be useful in providing students the competencies, expected products and performances; allowing them to participate in the planning, strategizing and accomplishing every activity while learning the content. Exposing students to these planned sequence of learning experiences resulted to students being involved in every teaching-learning process. Content was accessible; hence students were given an opportunity to monitor their own progress in every step of the way. This resulted to students appreciating their role in being accountable to their own and their classmates learning which in turn gave meaning to their every endeavor.

Given that all activities in Facebook Classroom entailed students acquiring, applying and showcasing different computer skills, they recognized how these help in their performance not only in the Computer Science subject but in other subjects as well. As revealed in their responses when asked about their level of agreement on the Computer Skills Development indicators, they claimed that attending Facebook Classroom not only allows them to practice computer skills when gathering information online but, in turn, expose them in learning practical skills that helps a lot in improving their outputs in other subjects.

In an on-line learning article discussing the importance of developing 21 st century skills, today's students love technology. But in preparation for tomorrow's success, they need to be able to use technology to develop critical thinking, problem solving, and other 21st century skills. In this manner, the researchers believed that exposure of students in a Social Media like Facebook, gave opportunities in developing these 21st century skills that, in turn, prepared them in today's digital world. These 21 st century skills were defined in the excerpt below, taken from the Infographic entitled, Preparing Students for 21st Century Success.

The activities that students participate in the Facebook Classroom provide such opportunities for the said skills development.

Table 7:-Correlation between Respondents' Perceived Facebook Classroom Effectiveness and their Level of Attitude, Interest and Motivation

\begin{tabular}{|l|c|c|c|}
\hline \multirow{2}{*}{ Facebook Classroom Related Factors } & \multicolumn{3}{|c|}{ Students' Performance } \\
\cline { 2 - 4 } & Attitude & Interest & Motivation \\
\hline Learning Materials Delivery & $.602^{* * *}$ & $.699^{* * *}$ & $.567^{* * *}$ \\
\hline Facilitating Communication & $.520^{* * *}$ & $.636^{* * *}$ & $.541^{* * *}$ \\
\hline Collaborative Learning & $.484^{* * *}$ & $.570^{* * *}$ & $.449^{* * *}$ \\
\hline Curriculum Content & $.608^{* * *}$ & $.803^{* * *}$ & $.668^{* * *}$ \\
\hline Computer Skills Development & $.638^{* * *}$ & $.749^{* * *}$ & $.685^{* * *}$ \\
\hline
\end{tabular}

Note: $N-78$, *** r-value is significant at $p<.000$

All Facebook Classroom-related factors revealed significant relationships (Table 7) with students' attitude, interest and motivation in learning Computer Science lessons as shown by the $r$-values significant at $p=.000$.

Further, Computer Skills Development as a Facebook related factor is highly significant to students' attitude (.638), interests (.749) a demotivation (.685). The result may imply that students recognize how activities done in Facebook Classroom (posting and sharing of information, presentation of data using different formats, transmission of these files in different Facebook facilities, etc.) are significant in developing their skills in the use of computers and other technologies that are present in the Internet environment. 
Attitude of Grade 8 students in Science High School towards their performance in Computer Science lessons and activities and how Facebook Classroom was utilized in terms of the variables of interest was revealed significant. This is evident on their positive response to every activity or task that was Facebook Classroom-related. Their responses to challenges towards attainment of good performance, successful products and highly appreciated output presentation proved to be influenced by how Facebook Classroom was used in many aspects of their learning. Students' engagement represented by the time and effort they invested in collaborating and sharing information in the platform facilitated better learning. Students' commitment also promoted individual sense of achievement due to positive student learning outcomes and their success in accomplishing every task given to them.

Grade 8 students' involvement and engagement in the many activities for Web design and Web programming in Facebook Classroom was evidently denoted in the results of their success in accomplishing and getting good marks in many Computer Science lessons and activities. The interesting outputs they could produce not only impresses the teacher but also themselves. During assessment and evaluation many positive reactions, good marks, and appreciation were observed. Proof that they went beyond expected from them to deliver which in turn inspired and piqued others' interest to do better with their outputs.

Many aspects of utilizing Facebook Classroom motivated students to learn Computer Science lessons. As they were part of the planning, organizing, and implementing of activities they tended to behave positively and their desire to perform well in every endeavor in and out of the school's classroom influenced their outputs and performance. It activated in them the desire to showcase their accomplishments and be proud of what they could produce. There was also a positive effect in how they delivered their outputs inside the classroom through the encouragement they achieved in their presence online because they could look for other information that will further their discussion about the topics assigned to them. Collaboration among group members were also evident in every aspect of the preparation, completion, production and evaluation of their outputs which also attributed to motivate them during presentation and practical application. Feedbacks swarmed online among students when asked "How does this Facebook Classroom help them?". Excepts were not included due to space limitation.

\section{Conclusions:-}

Based on the findings of this study, the following conclusions are drawn:

There is a significant relationship between respondents' performance in Computer Science and their perceived level of effectiveness on the designed Facebook Classroom. The hypothesis stating that there is no significant relationship between respondents' performance in Computer Science and the perceived Facebook Classroom effectiveness in terms of learning materials delivery, facilitating communication, collaborative learning, curriculum content, and computer skills development is not supported.

There is a significant relationship between respondents' perceived Facebook Classroom effectiveness and their attitude, interest and motivation in learning Computer Science lessons. The hypothesis stating that there is no significant relationship between the respondents' perceived Facebook Classroom effectiveness and their attitude, interest, and motivation is not sustained.

The respondents perceived that the designed Facebook Classroom brought improvement in their attitude towards learning the lessons in Computer Science because they felt encouraged when their outputs got positive reviews. That the activities done on the Facebook Classroom kept them interested and they looked forward for integrations of classroom activities using Facebook as the platform. The result suggested that the use of Facebook Classroom could greatly motivate students which brings forth progress in their performance in every Computer Science activity.

\section{Recommendations:-}

Considering the findings and conclusions of this study, the following recommendations are hereby suggested:

1. Since the study revealed that there is a significant relationship between the respondents' performance in Computer Science and the effectiveness of the designed Facebook Classroom, it is encouraged that San Pablo City Science High School may support the use of Designed Facebook Classroom Program Guidelines if they will adopt the program.

2. Seminars/workshops/trainings may be conducted to facilitate the proper use of Facebook Classroom as innovation for improving teaching-learning practices in other subjects, especially in Science and Technology.

3. The school may assist in improving facilities that will aid in the implementation of similar programs so that 
everyone can take opportunities in the sharing, collaborating and maintaining the effectiveness of such tools for effective teaching-learning practices across subjects.

4. Facebook Classroom may be utilized as the extension of the students' physical classroom activities or if they are already using such may the result and findings of this study be of help in giving them ideas on how to maximize its functionalities.

5. To help build a community of learners in the 21st century using Facebook as a platform for collaborative learning, computer skills development, and facilitation of a student-to-student and teacher-to-student communication.

6. A parallel study or an experimental research may be conducted focusing on the effectiveness of designed Facebook Classroom on the academic performance of students in different disciplines using a wider population in a regular high school curriculum.

\section{Acknowledgment:-}

Our deepest gratitude to the support of the school administrators of the Department of Education, Division of San Pablo City and the Laguna State Polytechnic University. Likewise, our thanks to the promising talents of Science High School for the cooperation and genuine enthusiasm shared to us during the conduct of this study.

\section{Bibliography:-}

1. Holmes, B. \& Gardner, J. (2006). E-Learning: Concepts and Practice. New Delhi: SAGE Publication Ltd, 2006.

2. Jacobs, H. H. (2010). Curriculum 21: Essential Education for a Changing World.

3. Padasas, T. P., Paquingan, A. R., Peñaflorida, A. R., \& Castro, M. F. (2009). Social Networking, p.9. Designing Web Pages, $2^{\text {nd }}$ Edition, 2009. Quezon City: Vibal Publishing House, Inc.

4. Salandanan, G. (2000). Teaching Approaches and Strategies. Quezon City: Katha Publishing Co., Inc.

5. Shelly, G. B., Cashman, T. J., \& Kosteba, L. A. (2001). Designing Web Pages, Book 3, p.9. Web Design Introductory Concepts and Techniques. Course Technology, Thomson Learning Asia.

\section{Unpublished Materials:-}

1. Aliazas, J. V. (2013). "Education Technology for Teaching \& Learning and Grade 7 Students' Proficiency Skills in Science and Technology in selected Secondary Schools in San Pablo City Division." Master's Thesis. Laguna State Polytechnic University, San Pablo City Campus.

2. Escario, P. U. (2005). "Effectiveness of PowerPoint Presentation on Some Applications of Definite Integrals: A Teaching Strategy." Master's Thesis. Eulogio "Amang" Rodriguez Institute of Science and Technology, Manila

3. Menandro, M. (2010). "Students Conceptual Understanding of Selected Chemistry Topics Using 5E Learning Model." Master's Thesis. Laguna State Polytechnic University, San Pablo City Campus.

4. Sandoval, P. J. C. (2008). "Design and Technology: An Innovative Approach in Teaching General Chemistry to Freshmen Students of Diploma in Hotel and Restaurant Management at the Laguna State Polytechnic University, San Pablo City Campus.” Master's Thesis. Laguna State Polytechnic University, San Pablo CityCampus.

\section{Journals:-}

1. Almobarraz, A. \& Farag, A. (2012). Graduate Students Attitude Towards E-learning. International Journal of Information Studies Volume 4 Number 2 April 2012, pp.41-47. Retrieved from: http://imamur.com/files/21.pdf

2. Alobiedat, A. \& Saraierh, R. (2010). The Student's Attitude toward Use Platform as Learning Resources at University of Granada. Review of European Studies Vol. 2, No. 2; December 2010. Retrieved from: https://openswad.org/paper/pdf/8459-26011-1-PB.pdf

3. Aydogan, F., \& Akyuz, A. (2010). Ikinci medya caginda Internet, p.66. Istanbul: Alfa.

4. Barkley, E. F., Cross, K. P., \& Major, C. H. (2005). Collaborative learning techniques: A handbook for college faculty. San Francisco: Jossey-Bass. Paperback (320 pp). ISBN: 978-0-7879-5518-2.

5. Cherry, K. (2014). Client-Centered Therapy: Carl Rogers' Non-Directive Approach to Therapy. Retrieved on October 12, 2014, from http://psychology.about.com/od/typesofpsychotherapy/a/client-centered-therapy.htm

6. Collin, P., Rahilly, K., Richardson, I. \& Third, A. (2011) The Benefits of Social Networking Services: A literature review. Cooperative Research Centre for Young People, Technology and Wellbeing. Melbourne.

7. Collins, J. (2013). Social Media and Language Learning: Why Classrooms Move Online. Retrieved from: http://edtechreview.in/trends-insights/insights/588-social-media-and-language-learning-why-classrooms-move- 
online

8. Dean, A. (2014). What is Facebook - Definition from WhatIs.com. Retrieved from: http://whatis.techtarget.com/definition/Facebook

9. Denning, P. J. (2005). Is Computer Science Science? CACM, April 2005/Vol. 48, No. 4, pp. 27 - 31. Retrieved from: http://www.cs.mtu.edu/ john/jenning.pdf

10. Eren, Ö. (2012). Students' Attitudes towards Using Social Networking in Foreign Language Classes: A Facebook Example. International Journal of Business and Social Science Vol. 3 No. 20 [Special Issue - October 2012]. Retrieved from: http://ijbssnet.com/journals/Vol_3_No_20_Special_Issue_October_2012/32.pdf

11. Gorghiu, L.M., Gorghiu, G., Dumitrescu, C., Olteanu, R.L. \& Glava, A.E. (2011). Integrating ICT in Traditional Training - Reactions of Teachers and Pupils' Involved in FISTE (A Future Way for In-Service Teacher Training across Europe) Project Activities. Retrieved from: http://www.sciencedirect.com/science/article/pii/ S1877042811020489

12. Holmes, B., Tangney, B., Gibbon, A. F., Savage, T., \& Mehan, S. (2001). Communal Constructivism: Students constructing learning for as well as with others. Ireland: Trinity College Dublin. Retrieved from: https://www.cs.tcd.ie/publications/tech-reports/reports.01/TCD-CS-2001-04.pdf

13. Irwin, C. G., Ball, L. E., Desbrow, B., \& Leveritt, M. (2012). Students' Perceptions of Using Facebook as an Interactive Learning Resource at University. Retrieved from: http://www.ascilite.org.au/ajet/ajet28/irwin.html

14. Lepi, K. (2014). How to Use Social Media in Education (Part 2 of 2). Retrieved from: http://www.edudemic.com/social-media-in-education-series/

15. Llorens, F. \& Capdeferro, N. (2011). "Facebook's Potential for Collaborative e-Learning". Revista de Universidad y Sociedad del Conocimiento (RUSC). Vol. 8, No 2, pp. 197-210. UOC. Retrieved March 4, 2015, from: $\quad<$ http://rusc.uoc.edu/ojs/index.php/rusc/article/view/v8n2-llorens-capdeferro/v8n2-llorenscapdeferroeng>

16. Mayrath, M. C., Nihalani, P., \& Perkins, S. (2011). Digital Texts and the Future of Education: Why Books? Retrieved from: http://www.educause.edu/ero/article/digital-texts-and-future-education-why-books

17. McGuirk, R. \& Donnelly, A. (2003). Communal Constructivism and its Potential for Inclusion of Students with Visual Impairment. Department of Computer Science, Trinity College, Dublin. Retrieved from: http://www.tschlotfeldt.de/elearning-wiki/Communal_Constructivism

18. Murniati, T. (2012). Initiating Students' Interest in Writing by Using Facebook 1. Retrieved October 5, 2013, from: http://www.academia.edu/6620460/Initiating_Students_Interest_in_Writing_by_Using_Facebook_1

19. Muttaqin, W. M. (2013). Understanding Online Language Learning. Retrieved from: https://hellowildan.wordpress.com/2013/03/07/\%CF\%B5-learning-theory-communal-constructivism/

20. Onike, R. (2010). Educational Implications of Theory of Communal Constructivism. Retrieved from: http://searchwarp.com/swa596784-Educational-Implications-Of-Theory-Of-Communal-Constructivism.htm

21. Passey, D. \& Rogers, C., Machell, J. \& McHugh, G. (2004). The Motivational Effect of ICT on Pupils. Retrieved

from: http://downloads01.smarttech.com/media/research/international_research/uk/lancaster_report.pdf

22. Ramaha, N. T., Fauzy, W. M., Ismail, W. (2012). Assessment of Learner's Motivation in Web Based ELearning. International Journal of Scientific \& Engineering Research Volume 3, Issue 8, August-2012. Retrieved from: http://www.ijser.org/researchpaper\%5CAssessment-of-Learners-Motivation-In-Web-Based-ELearning.pdf

23. Rambe, P. (2012). Constructive Disruptions for Effective Collaborative Learning: Navigating the Affordances of Social Media for Meaningful Engagement. Retrieved from: www.ejel.org/issue/download.html?idArticle $=184$

24. Roblyer, M. D., McDaniel, M., Webb, M., Herman, J., \& Witty, J.V. (2010). Findings on Facebook in Higher Education: A Comparison of College Faculty and Student Uses and Perceptions of Social Networking Sites. Retrieved November 7, 2014 from: http://eric.ed.gov/?id=EJ886995

25. Rosado-Feger, A., Khurrum, M., \& Bhutta, S. (2013). Student Attitudes toward Using Facebook for Education: A Survey. Retrieved from: http://connection.ebscohost.com/c/articles/88837777/student-attitudes-toward-usingfacebook-education-survey

26. Santosh, B. K. (2013). Steps Into the 21st Century Classroom. Retrieved from: http://edtechreview.in/trendsinsights/insights $/ 576$

27. Shaw, K. (n.d.). Programme Manual: Section 2. Creating Online Learning Materials. Retrieved from: http://www.ukoln.ac.uk/nof/support/manual/learning-materials/

28. Shih, C. \& Gamon, J. A. (2002). Relationships among Learning Strategies, Patterns, Styles, and Achievement in Web-based Courses. Journal of Agricultural Education 11 Volume 43, Number 4, 2002. Retrieved from: 
http://pubs.aged.tamu.edu/jae/pdf/Vol43/43-04-01.pdf

29. Surgenor, P. (2010). Teaching Toolkit: How Students Learn 4. Retrieved from: http://www.ucd.ie/t4cms/UCDTLT0019.pdf

30. Tiryakioglu, F. \& Erzurum, F. (2011). Use of Social Networks as an Education Tool. Contemporary Educational Technology, 2011, 2(2), 135-150. Retrieved from: http://www.cedtech.net/articles/22/223.pdf

31. Vota, W. (2010) 4 Reasons why Facebook is an Educational Tool for Schools. Retrieved from: http://www.ictworks.org/2010/12/03/4-reasons-why-facebook-educational-tool-schools/

32. Williams, K. C., \& Williams, C. C. (2011). Five key ingredients for improving student motivation. Research in Higher Education Journal, 121-23.

\section{Internet Sources:-}

1. Computer Science. (n.d.) American Heritage ${ }^{\circledR}$ Dictionary of the English Language, Fifth Edition. (2011). Retrieved November 15, 2014from: http://www.thefreedictionary.com/computer+science

2. Curriculum (2014). The Glossary of Education Reform. Retrieved from http://edglossary.org/curriculum/

3. Dance, J. (2008). What is Innovation? 30+ definitions lead to one fresh summary. Retrieved from: http://www.freshconsulting.com/what-is-innovation/

4. Davis, M. R. (2010). Social Networking Goes to School. Digital Directions. Education Week. Retrieved November 15, 2014 from: http://www.edweek.org/dd/articles/2010/06/16/03networking.h03.html

5. Defining the Curriculum Content. (n.d.) United Nations Educational, Scientific and Cultural Organization. Retrieved March 4, 2015, from: http://www.unesco.org/new/en/education/themes/strengthening-education-systems/qualityframework/technical-notes/defining-curriculum-content/

6. Editorial Projects in Education Research Center. (2011, September 1). Issues A-Z: Technology in Education. Education Week. Retrieved October 12, 2013, from http://www.edweek.org/ew/issues/technology-in-education/

7. Ellison, N. B. \& Boyd, D. (2013). Sociality through Social Network Sites. In Dutton, W. H. (Ed.), The Oxford Handbook of Internet Studies. Oxford: Oxford University Press, pp. 151-172. Retrieved from: www.danah.org/papers/2013/SocialityThruSNS-preprint.pdf

8. General Guidelines for the Assessment and Rating of Learning Outcomes. (2012).DepEd Order 73, s. 2012 Guidelines on the Assessment and Rating of Learning Outcomes Under the K to 12 Basic Education Curriculum, Enclosure1. Retrieved from: http://www.deped.gov.ph/orders/do-73-s-2012

9. Haworth, W. (2001). Developing Computer Skills. IC - "the new chalk." Retrieved from: https://www.llas.ac.uk/resources/gpg/1449

10. Interest. (n.d.). In MacMillan from: http://www.macmillandictionary.com/us/dictionary/american/interest_1

11. Motivation. (n.d.). In Merriam-Webster Dictionary. Retrieved from: http://www.merriamwebster.com/dictionary/motivation

12. Patidar, J. (2014). Non-experimental Research Design. Retrieved from: http://www.slideshare.net/drjayeshpatidar/nonexperimental-research-design?related=1

13. Performance. (n.d.). In Microsoft Encarta Dictionary 2009 [Computer Software].

14. Preparing Students for 21st Century Success. (n.d.). Infographic: Preparing Students for 21st Century Success. Defining 21st Century Skills. Retrieved from: www.learning.com/21cs/info/

15. Russell, J. (2011) Philippines named social networking capital of the world. Retrieved from: http://asiancorrespondent.com/54475/philippines-named-the-social-networking-capital-of-the-world-indonesiamalaysia-amongst-top-10/

16. The Importance of Developing Computer Skills. (2010). Iceni Technology. Retrieved from: http://www.iceni.com/articles/the-importance-of-developing-computer-skills-1288086076.htm

17. Why Integrate Technology into the Curriculum? The Reasons Are Many. (2008). Edutopia. Retrieved from: http://www.edutopia.org/technology-integration-introduction

18. Wolfe, A. M. (2007). Student Attitudes Towards Social Networks and Learning Modalities. Retrieved from: http://alisonwolfe.com/wordpress/wp-content/uploads/Student_Attitudes_Social_Networks1.pdf 